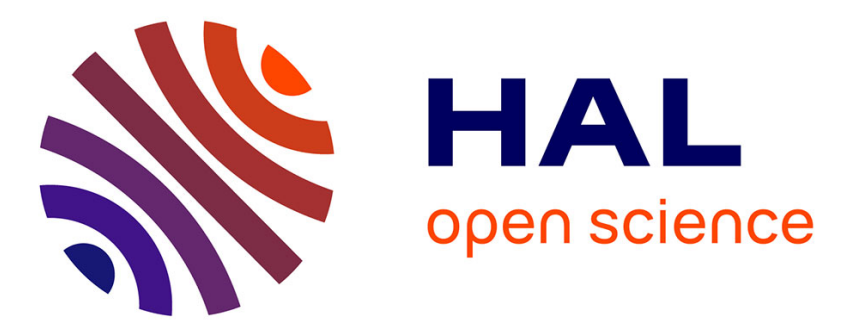

\title{
Reproductive effort in the domesticated red alga Agarophyton chilense: differences between farms and natural populations
}

Juan Diego Gaitán-Espitia, Marie Laure Guillemin, Sara Usandizaga, Paula Valenzuela, Christophe Destombe

\section{To cite this version:}

Juan Diego Gaitán-Espitia, Marie Laure Guillemin, Sara Usandizaga, Paula Valenzuela, Christophe Destombe. Reproductive effort in the domesticated red alga Agarophyton chilense: differences between farms and natural populations. Journal of Applied Phycology, 2021, 10.1007/s10811-020-02325-8 . hal-03106283

\section{HAL Id: hal-03106283 \\ https://hal.sorbonne-universite.fr/hal-03106283}

Submitted on 11 Jan 2021

HAL is a multi-disciplinary open access archive for the deposit and dissemination of scientific research documents, whether they are published or not. The documents may come from teaching and research institutions in France or abroad, or from public or private research centers.
L'archive ouverte pluridisciplinaire HAL, est destinée au dépôt et à la diffusion de documents scientifiques de niveau recherche, publiés ou non, émanant des établissements d'enseignement et de recherche français ou étrangers, des laboratoires publics ou privés. 


\section{Reproductive effort in the domesticated red alga Agarophyton chilense: differences between farms and natural populations}

Sara Usandizaga ${ }^{1}$, Paula Valenzuela ${ }^{2,3}$, Juan Diego Gaitán-Espitia ${ }^{4}$, Christophe Destombe ${ }^{5}$ \& Marie Laure Guillemin ${ }^{2,5, \mathrm{a}}$

${ }^{1}$ Universidad de Los Lagos, Centro i mar and CeBiB, Camino Chinquihue Km 6, Puerto Montt, Chile.

${ }^{2}$ Instituto de Ciencias Ambientales y Evolutivas, Universidad Austral de Chile, Casilla 567 Valdivia, Chile.

${ }^{3}$ Laboratorio Costero Calfuco, Instituto de Biología Marina "Jürgen Winter" Universidad Austral de Chile, Casilla 567, Valdivia, Chile

${ }^{4}$ SWIRE Institute of Marine Sciences \& School of Biological Sciences, The University of Hong Kong, Pokfulam Road, Hong Kong, SAR, China.

${ }^{5}$ CNRS, Sorbonne Université, Pontificia Universidad Católica de Chile, Universidad Austral de Chile, UMI 3614, Evolutionary Biology and Ecology of Algae, Station Biologique de Roscoff, CS 90074, F-29688, Roscoff, France

a Corresponding author: Marie-Laure Guillemin. Instituto de Ciencias Ambientales y Evolutivas, Facultad de Ciencias, Universidad Austral de Chile, Casilla 567 Valdivia, Chile. Phone: +5663 221704; fax: $+56 \quad 63$ 221344. Email address: marielaure.guillemin@gmail.com

Running title: Trade-off between reproduction and growth Abstract 
Macroalgal domestication and farming can induce significant ecological and biological changes in exploited species. In the red macroalga, Agarophyton chilense, marine farming is based on clonal propagation by cuttings of the largest plants. This type of mass selection by farmers can have a considerable impact on the life history characteristics of cultivated strains. In this study, we investigated the potential effect of this type of selection on the reproduction in A. chilense, comparing female gametophytes from the natural and farmed populations. Our results showed strong differences between these two types of populations. As expected, individuals were larger in the farm than in the wild population. On the other hand, the number of cystocarps per centimeters of fronds was ten times lower in the farm than in the natural population. These differences suggest that artificial selection and cultivation environment significantly modify life-history traits in this macroalga. Moreover, the positive relationship between female size and number of cystocarps per centimeters of fronds observed in Dichato point out to the possible existence of cost of reproduction in $A$. chilense, with bigger females allocating more resources or energy to reproductive structures in natural populations.

Key index words: Aquaculture, Gracilariales, cystocarp production, reproductive effort, investment, trade-off, vegetative growth.

\section{Introduction}

New macroalgal cultivation methods, most often adapted from the agricultural practices of terrestrial plants, are being developed in marine aquaculture (Robinson et al. 2013, Hafting et al. 2015). These new cultivation practices in human-controlled 
environments are associated with significant ecological changes (Smith 2016), as well as alterations in the biology and reproduction of cultivated species (Zeder 2015; Valero et al. 2017). In macroalgae, these domestication processes are still poorly understood and further research, integrating knowledge on the evolutionary biology and ecology of natural populations and on the selective pressures exerted by cultivators, is therefore necessary to promote sustainable macroalgal aquaculture (for review Valero et al. 2017). In some species of red algae, cultivation is based on the clonal propagation of rapidly growing algal strains on farms. This type of clonal multiplication can generate an important impact in the characteristics of the biological cycle and the genetic diversity of cultivated species (Guillemin et al. 2008, Valero et al. 2017). One example of this is the Rhodophyta Agarophyton chilense (C.J.Bird, McLachlan et E.C.Oliveira) Gurgel, J.N.Norris et Fredericq previously referred as Gracilaria chilensis. This species has been domesticated and cultivated in Chile since the early 1970s, mainly for agar production (Buschmann et al. 2008). It has been hypothesized that farmers have unconsciously selected for fast growth rate genotypes in farms, potentially simultaneously counter-selecting against high reproductive investment (Guillemin et al. 2008; Usandizaga et al. 2019). Indeed, in controlled laboratory conditions, trade-offs have been reported between growth and reproduction for this species (Guillemin et al. 2013).

Agarophyton chilense presents a typical isomorphic haplodiplontic life cycle with two free-living isomorphic generations: haploid gametophytes (males and females) and diploid tetrasporophyte. When released, the haploid tetraspores attach to the substrate to give new gametophyte individuals consisting of perennial holdfasts from which spaghetti-like thalli grow. Male gametes (spermatia) are released in the water column. Female thalli bear uniformly distributed gametangia, which consist of three cells and can be observed only on 
thallus sections under microscope (Kling and Bodard 1987). Fertilization occurs on the female individual and involves complex cytological events, resulting in the formation of a cystocarp on the female (Hommersand and Fredericq 1990). The development of a haploid pericarp is induced, within which the zygote divides mitotically (gonimoblast), protected and nurtured by the female. After a few weeks of maturation, the cystocarp liberates thousands of diploid spores named carpospores (Lefebvre et al. 1987; Fredericq and Hommersand 1989; Kain and Destombe 1995). These carpospores, after their release, give rise to new tetrasporophyte individuals.

Two types of populations, potentially presenting strong difference in reproductive investment (Guillemin et al. 2008), are found in Chile: (1) natural populations formed by individuals growing from a perennial holdfast and fixed to hard substratum and (2) floating thalli that grow and propagate by self-replication in sandy and muddy bays and estuaries (i.e., farms). The natural populations are maintained by sexual reproduction and spores recruitment (Guillemin et al. 2008). In these populations fertile tetrasporophytes, male and female gametophytes are frequently encountered (Meneses 1996; Vieira et al. 2018a). On the other hand, farmed populations - growing on muddy or sandy beds - are composed by a high proportion of genetically identical units (Guillemin et al. 2008), mainly maintained through human-assisted thallus breakage and embedding. Most of the Chilean crops of $A$. chilense are composed of clonal tetrasporophytes, except the farmed population in Lenga $\left(36^{\circ} 45^{\prime} \mathrm{S}\right.$, $73^{\circ} 11^{\prime} \mathrm{W}$ ), where growing thalli are mainly female gametophytes (Guillemin et al. 2008). Farmed thalli are generally recognized to be poorly reproductive sexually (Prieto et al. 1991). However, even if slightly less reproductive individuals have been observed in farms, no clear significant differences have been reported in terms of frequency of reproductive thalli when compared to natural populations (Guillemin et al. 2008). 
In haplodiplontic red macroalgae, the quantification of cystocarps production is simple since these reproductive structures are visible with the naked eye and have hemispherical fruiting bodies which develop on the female gametophyte after fertilization (Richerd et al. 1993, Kamiya and West 2010). In A. chilense (as G. chilensis) and Gracilaria domingensis (Kützing) Sonder, the vegetative growth of female gametophytes decreases after fertilization during the development of cystocarps (Santelices and Varela 1995; Guimarães et al. 1999). These observations are consistent with resource allocation theory which predicts that reproduction imposes a cost on an organism (for reviews see DeWreede and Klinger 1988; Santelices 1990). The number and size of cystocarps produced by a female has been used to measure red macroalgae reproductive output (Edyvean and Ford 1984). The reproductive effort, classically defined as the relative amount of resources allocated to reproduction over a defined period of time, is much more complex to measure. The ratio of the reproductive biomass to that of the whole plant or the vegetative biomass has been used as a proxy of reproductive effort in Fucales (Cousens 1986; Ang 1992; Åberg 1996) and crustose macroalgae (Edyvean and Ford 1984). In red macroalgae, reproductive output will depend on the female genotype and the number of gametangia it produces (Engel and Destombe 2002), the quantity and quality of male gametes (Engel and Destombe 2002; Engel et al. 2002) and the female investment in cystocarps (Kamiya and Kawai 2002). However, reproductive output and reproductive effort are sometimes difficult to distinguish, and cystocarp production per unit area or frond length has been used as an indicators or proxy for reproductive effort (Krueger-Hadfield et al. 2013). In this study, we examined the relationship between thallus size and reproductive output in natural versus crop populations. We hypothesize that clonal propagation and artificial selection in farmed populations have 
induced reproductive costs in A. chilense evidenced by the trade-off between thallus size and cystocarps production.

\section{Materials and methods}

\section{1 . Collection and maintenance of algal material}

In A. chilense, gametophytes and tetrasporophytes share the same gross morphology and the phase and sex can only be recognized during the reproduction period. Even if reproductive individuals could be encountered all year round and reproductive season is not clearly defined for A. chilense, the highest percentage of reproductive individuals is encountered during summer (December to April in the southern hemisphere, Guillemin M-L. unpublished data) and the highest spore production occur at the end of summer / beginning of autumn (after February, Vieira et al. 2018b).

Reproductive female gametophytes were collected in March 2009 in the natural population of Dichato $\left(36^{\circ} 32^{\prime} \mathrm{S}, 72^{\circ} 56^{\prime} \mathrm{W}\right)$ and in the crop of Lenga $\left(36^{\circ} 45^{\prime} \mathrm{S}, 72^{\circ} 11^{\prime}\right.$ W) separated geographically by about $25 \mathrm{~km}$ (see Figure 1). We sampled different genets (i.e. females with distinct holdfasts) in Dichato and different ramets (i.e. thalli developing from an under-ground thallus system) in the farm of Lenga. In Dichato, females with cystocarps were selected directly in the field. In Lenga, a farm where much less reproductive structures are generally encountered (Guillemin et al. 2008), only well-isolated thalli (i.e., a well-defined group of fronds surrounded by at least $10 \mathrm{~cm}$ of sand from any other A. chilense) were randomly selected $(\mathrm{N}=100)$ and the above-ground biomass was collected. In each site, individuals were collected in an area no larger than $20 \mathrm{~m}^{2}$. The collected individuals were placed separately in plastic bags and transported in a cooler to the "Calfuco Water Resources 
Coastal Laboratory", in Valdivia. Once at the laboratory, the presence of cystocarps was revised thoroughly under a stereoscope microscope (Zeiss Stemi DV4/DR) and speciesspecific molecular sex markers were amplified in vegetative individuals from Lenga using the protocol defined by the authors (Guillemin et al. 2012). In total, 20 females were selected in each population for further analyses.

\subsection{Biomass and reproductive investment estimators}

In the natural population of Dichato, all females were attached to the substratum and primary fronds were defined as thalli directly growing from the holdfast. In the farm of Lenga, after cutting individuals at sand level, the independent thalli forming the clump were defined as primary fronds. In both populations all primary fronds and up to seven secondary fronds per female were measured. For each female, we measured four estimators of biomass: i) the dry weight $(\mathrm{g})$, ii) the volume of the thallus (i.e., the volume of a cylinder of the maximum length and maximum diameter of the thallus in $\mathrm{cm}^{3}$ ), and iii) the length of primary fronds $(\mathrm{cm})$ and iv) the length of secondary fronds $(\mathrm{cm})$. As reproductive output estimators, we measured: i) the number of cystocarps observed per centimeter of primary fronds (no. of cystocarps $\cdot \mathrm{cm}^{-1}$ ) and, ii) the number of cystocarps observed per centimeter of secondary fronds (no. of cystocarps $\cdot \mathrm{cm}^{-1}$ ). Hereafter, the diameter of the cystocarps was measured under a stereoscope microscope in the lab (Zeiss Stemi DV4/DR). Up to 60 cystocarps were measured per female in Dichato and up to 45 in Lenga. In order to verify for the presence of viable carpospores in the cystocarps, six fragments of fronds carrying cystocarps were taken haphazardly in each population and fixed in $10 \%$ formalin-seawater. Material embedded in paraffin was sectioned in a microtome (Leica RM 2035) and stained with dilute methylene 
blue or haematoxylin-eosin for observation of general morphology. Photomicrographs were taken with an Olympus BX41 microscope.

\subsection{Statistical analysis}

Data were tested for homogeneity of variances and normal distribution using Levene's and Shapiro-Wilk tests, respectively. When existence of non-normal residuals and/or heteroscedasticity was detected, data were logarithmically transformed prior analyses. Student $\mathrm{T}$ tests were performed to evaluate differences between Dichato and Lenga whenever homogeneity of variances was achieved (i.e., dry weight, volume of the thallus and primary and secondary fronds length), while the non-parametric Mann-Whitney U-tests were used when homogeneity of variances was not fulfilled after data transformations (i.e., number of cystocarps per centimeter of primary and secondary frond). Correlation between length of primary fronds and cystocarps production in females were tested using Spearman rank correlation, performed independently in Dichato and Lenga. All differences were considered significant at $p$-value $<0.05$ and correction for multiple testing was carried out using the Bonferroni method. All analyses were performed in R (3.6.3 version) (R Core Team 2016).

\section{Results}

In the farm of Lenga, cystocarps were observed in only $80 \%$ of the females (16 out of 20), whereas in the natural population of Dichato, all 20 females studied bear cystocarps. Strong differences were observed between Dichato and the crop of Lenga for female size (length of primary and secondary fronds, volume of thallus and dry weight, $p<0.05$ for all Student $\mathrm{T}$ tests, Table 1) and production of cystocarps (number of cystocarps observed per centimetre of primary and secondary frond, $p<0.05$ for both Mann-Whitney U-tests, Table 
1). Females from Dichato were much smaller than the ones from Lenga (dry weight, volume of thallus and length of primary fronds, Table 1). The females sampled in the natural population of Dichato were characterized by a higher production of cystocarps with a number of cystocarps per centimeter of frond ten times higher for primary fronds and twenty times higher for secondary fronds than the females from Lenga (Table 1). No significant difference in cystocarp size was observed between populations (Table 1). The number of cystocarps observed along the primary fronds was positively correlated with their length in Dichato (Figure 2) but not in Lenga (Figure 2). The number of cystocarps along the secondary fronds was not correlated with their length irrespective of the locality ( $\mathrm{rs}=-0.234, p=0.306$ and $\mathrm{rs}$ $=-0.137, p=0.575$ in Dichato and Lenga, respectively, data not shown). Finally, carpospores were observed in cross-section of cystocarps in both localities (Figure 3).

\section{Discussion}

Our results demonstrated that female gametophytes of Agarophyton chilense are bigger and less sexually reproductive in farms than in natural populations. These differences suggest that cultivation significantly modified life-history traits of this macro alga. In this species, cultivation techniques have usually relied only on replanting of thallus cuttings. This

practice allows farmers to selectively multiply (consciously or unconsciously) the phenotypes with the highest biomass production but also the ones best adapted to these new growing conditions. We propose that the ecological modification of the environment and the clonal selection oriented towards the production of biomass operated by farmers (i.e., the first step in the domestication process of the species; Valero et al. 2017), had the indirect consequence of reduced investment in sexual reproduction leading to a much lower reproductive output. Observations of the effect of domestication on the reproduction on 
plants suggest that human selection for increased vegetative propagation led to architectural changes that resulted in reduced sexual fecundity (in cassava, McKey et al. 2010) and fertility (e.g. in potato, Simmonds 1997; and yams, Segnou et al. 1992). In cultivated seaweeds, strong evidence for domestication exist (Agarophyton, Guillemin et al. 2008 and Kappaphycus, Ask and Azanza 2002). Nevertheless, no clear results have been obtained regarding the diminished reproductive output as a consequence of domestication process in macroalgae yet.

Field studies focused on natural populations of A. chilense have shown that the probability of a frond to become fecund is size-dependent (Vieira et al. 2018a and b). In the present study, a positive relationship between the size of the primary fronds and the number of cystocarps produced was observed in the natural population (Dichato). This could be explained by the fact that the external part of this organ (the pericarp) is produced directly by the female. Indeed, in the Florideophyceae, the size of the cystocarp and the number of spores produced by cystocarp are related to the thallus biomass supporting the reproductive structures (in Antithamnion nipponicum, Ceramium boydenii and C. Japonicum; Kamiya and Kawai 2002). In the same way, in brown algae, positive correlations between thallus size and the proportion of biomass allocated to reproductive tissue have been reported in various species (Ascophyllum nodosum, Åberg 1996; Hizikia fusiformis, Zou et al. 2006; Sargassum thunbergii, Zhang et al. 2009) and were related to the higher number of reproductive meristems available for receptacle production present along the thalli of larger individuals (Zhang et al. 2009). On the other hand, the positive relationship between the size of the frond and the production of cystocarps was not observed in females from the farmed population (Lenga). In addition, these females had on average a production of cystocarps ten times lower than in the natural population. As the development of cystocarps occurs after the fertilization 
(Hommersand and Fredericq 1990), this result could be linked either to a low number of carpogonium (female reproductive structure) per female or to a general low availability of male gametes in this farm. Indeed, contrary to what is observed in natural populations where the sex ratio is generally balanced (Guillemin et al. 2008), the number of males in Lenga is reduced (data not shown). Farmers seem to avoid males in A. chilense crops probably due to their lower vegetative growth rate, when compared to females or tetrasporophytes (Guillemin et al. 2013). Despite these differences between the two types of populations, we assume that the few reproductive males observed in the farmed population can actively participate in fertilization. Furthermore, we cannot rule out the hypothesis that the male gametes could come from neighboring natural populations, maintaining some degree of sexual reproduction in the farm. It has been shown in Gracilaria gracilis that spermatia have a lifespan of more than 6 hours and can be carried by currents (Destombe et al. 1990).

According to life-history theory, reproductive cost implies trade-offs in resource distribution, expressed as changes in future growth, fecundity, and/or survival (Stearns 1992; Álvarez-Cansino et al. 2010; Vieira et al. 2018a; Vieira et al. 2018b). In this context, some empirical studies in plants have documented trade-offs in terms of allocation of energy and limited resources, particularly between reproduction and vegetative growth (Ashman 1994; Campbell 2000; Ehrlén and Groenendael 2001; Henriksson 2001; Obeso 2002, 2004; Bañuelos and Obeso 2004; Álvarez-Cansino et al. 2010). In some Rhodophyta, gametophytic females have been shown to present a clear decrease in vegetative growth when reproductive (Santelices and Varela 1995; Guimarães et al. 1999) as resources are diverted from the adjacent thallus to allow the development of cystocarps (Kamiya and Kawai 2002). In A. chilense, vegetative fronds show a higher survival and a better growth rate than reproductive ones irrespective of the type of individual analyzed (male gametophyte, female gametophyte, 
or tetrasporophyte) (Guillemin et al. 2013). Studies monitoring A. chilense in natural populations also support the existence of a trade-off between survival and reproduction (Vieira et al. 2018a and b). A study developed in central Chile focusing on gametophytes of the two intertidal red algae Ahnfeltia durvillaei and Gymnogongrus furcellatus, suggests the existence of reproductive costs and trade-offs between growth and fecundity (Camus 1992). The study documented a size-independent threshold in reproductive effort for each species. In the same way, field studies in brown algae support the existence of a reproductive cost, evidenced by decrease in growth or survival rates in reproductive individuals (Ang 1992; Åberg 1996).

In this study, despite the lower production of cystocarps in females from the farmed population, these structures seem to be fertile and produce carpospores. However, it is very unlikely that these spores will succeed in germinating in this type of sandy environment, which could explain the low frequency of tetrasporophytes in this farm. The evolution of functionally sterile clonal thalli in farms has been previously hypothesized in A. chilense as a result of farming techniques mostly/only based on clonal multiplication of vegetative thalli (Guillemin et al. 2008). The theoretical framework behind this evolutionary hypothesis suggests that organisms maintained only by asexual reproduction for a number of generations could lose their ability of reproduce sexually due to the accumulation of sterility mutations in populations where sexual recruitment is impaired by the environment ("use it or lose it" hypothesis; Eckert 2002). In these cases, sterility arises through the accumulation of mutations in genes necessary for sexual reproduction (i.e. genes involved in meiosis, gamete production or necessary for gametes encounter and fusion), these becoming non-functional. The lack of sexual reproduction during various generations impedes counter selection and the purge of the mutation load accumulated along these genes (Eckert 2002). Our results do 
not, however, support the idea of a sterilization of the Lenga farm clonal female thalli. This result may be explained by the relatively recent domestication of A. chilense (Buschmann et al. 1995; Valero et al. 2017) and evolutionary pathway to sterilization could still be ongoing in this species. However, measurements made during the present study include only the cystocarps formation while other important steps in the sexual life cycle have not been considered (e.g., the capacity of the carpospores to settle, germinate and grow) (Fletcher and Callow 1992). Complementary common garden experiments and genomic screening are now needed to test for differences in survival and growth of carpospores produced by females from natural and farmed populations and study the potential load of accumulated mutation in genes necessary for sexual reproduction.

\section{Acknowledgments}

This research was funded by Fondo Nacional de Desarrollo Científico y Tecnológico, Gobierno de Chile (FONDECYT \#1090360 and \#1170541) awarded to M-L. Guillemin. JDGE was supported by the Research Grants Council (ECS 27124318) of Hong Kong. M-L G and CD benefited from the support of the French National Research Agency with regard to an investment expenditure programme IDEALG (ANR-10-BTBR-04), and from the international research network BioDiversity, Evolution and Biotechnology of Marine Algae

(GDRI No.0803). We thank P. Antileo, K. Contreras and O. Huanel for their help in the field.

\section{References}

Åberg P (1996) Patterns of reproductive effort in the brown alga Ascophyllum nodosum. Mar Ecol Prog Ser 138:199-207. 
Álvarez-Cansino L, Zunzunegui M, Barradas MCD, Esquivias MP (2010) Gender-specific costs of reproduction on vegetative growth and physiological performance in the dioecious shrub Corema album. Ann Bot 106:989-998.

Ang PO (1992) Cost of reproduction in Fucus distichus. Mar Ecol Prog Ser 28:25-35.

Ashman LT (1994) A dynamic perspective on the physiological cost of reproduction in plants. Am Nat 144:300-316.

Ask EI, Azanza RV (2002): Advances in cultivation technology of commercial eucheumatoid species: a review with suggestions for future research. Aquaculture 206:257-277.

Bañuelos MJ, Obeso JR (2004) Resource allocation in the dioecious shrub Rhamnus alpinus: the hidden costs of reproduction. Evol Ecol Res 6:1-17.

Bird CJ, McLachan J, Oliveira EC (1986) Gracilaria chilensis sp. nov; (Rhodophyta, Gigartinales), from Pacific South America. Can J Bot 64:2928-2934.

Buschmann AH, Westermeier R, Retamales C (1995) Cultivation of Gracilaria in the seabottom in southern Chile: A review. J Appl Phycol 7:291-301.

Buschmann AH, Hernández-González MC, Varela DA (2008) Seaweed future cultivation in Chile: perspectives and challenges. Int J Environ Pollut 33:432-456.

Camus PA (1992) Size-specific reproductive parameters in red algae: a comparative analysis for two sympatric species from Central Chile. Oecología 92:450-456.

Campbell DR (2000) Experimental test of sex allocation theory in plants. Trends Ecol Evol $15: 227-232$. 
Cousens R (1986) Quantitative reproduction and reproductive effort by stands of the brown alga Ascophyllum nodosum (L.) Le Jolis in south-eastern Canada. Estuar Coast Shelf Sci 22:495-507.

De Wreede RE, Klinger T (1988) Reproductive strategies in algae. Plant reproductive ecology: patterns and strategies 267-284.

Destombe C, Godin J, Remy JM (1990) Viability and dissemination of spermatia of Gracilaria verrucosa (Gracilariales, Rhodophyta). Hydrobiologia 204/205:219-223.

Eckert CG (2002) The loss of sex in clonal plants. Evol Ecol 15:501-520.

Edyvean RGJ, Ford H (1984) Population biology of the crustose red alga Lithophyllum incrustans Phil. 3. The effects of local environmental variables. Biol J Linn Soc 23:365-374.

Ehrlén J, Groenendael JV (2001) Storage and the delayed cost of reproduction in the understorey perennial Lathyrus vernus. J Ecol 89:237-246.

Engel CR, Destombe C (2002) Reproductive ecology of an intertidal red seaweed, Gracilaria gracilis: Influence of high and low tides on fertilization success. J Mar Biol Ass UK 82:1-4.

Engel CR, Valero M, Lagadeuc Y, Destombe C (2002) Non-random mating in controlled multiple-donor crosses in Gracilaria gracilis (Gracilariaceae, Rhodophyta). Eur J Phycol $37: 179-190$.

Fredericq S, Hommersand MH (1989) Proposal of the Gracilariales Ord. Nov. (Rhodophyta) based on an analysis of the reproductive development of Gracilaria verrucosa. J. Phycol 25:213-227. 
Fletcher RL, Callow ME (1992) The settlement, attachment and establishment of marine algal spores. Br Phycol J 27:303-329.

Guillemin ML, Faugeron S, Destombe C, Viard F, Correa JA, Valero M (2008) Genetic variation in wild and cultivated populations of the haploid-diploid red alga Gracilaria chilensis: How farming practices favor asexual reproduction and heterozigosity. Evolution 62:1500-1519.

Guillemin ML, Huanel OR, Martínez EA (2012) Characterization of genetic markers linked to sex determination in the haploid-diploid red alga Gracilaria chilensis. J Phycol 48:365372.

Guillemin ML, Valenzuela P, Gaitán-Espitia JD, Destombe C (2013) Evidence of reproductive cost in the triphasic life history of the red alga Gracilaria chilensis (Gracilariales, Rhodophyta). J Appl Phycol 25:215-224.

Guimarães M, Plastino EM, Oliveira EC (1999) Life history, reproduction and growth of Gracilaria domingensis (Gracilariales, Rhodophyta) from Brazil. Bot Mar 42:481486.Hafting JT, Craigie JS, Stengel DB, Loureiro RR, Buschmann AH, Yarish C, Edwards MD, Critchley AT (2015) Prospects and challenges for industrial production of seaweed bioactives. J Phycol 51:821-837.

Henriksson J (2001) Differential shading of branches or whole trees: survival, growth, and reproduction. Oecologia 126:482-486.

Hommersand MH, Fredericq S (1990) Sexual reproduction and cystocarp development. In: Cole KM, Sheath RG (eds) Biology of the Red Algae. Cambridge University Press, pp 305345.

Kain JM, Destombe C (1995) A review of the life history, reproduction and phenology of Gracilaria. J Appl Phycol 7:269-281. 
Kamiya M, Kawai H (2002) Dependence of the carposporophyte on the maternal gametophyte in three ceramiacean algae (Rhodophyta), with respect to carposporophyte development, spore production and germination success. Phycologia 41:107-115.

Kamiya M, West JA (2010) Investigations on reproductive affinities in red algae. In: Seckbach J, Chapman DJ (eds) Red Algae in the Genomic Age. Springer, Dordrecht, pp 77109.

Kling R, Bodard M (1987) Morphogenesis of the frond of Gracilaria verrucosa (Hudson) Papenfuss: the differentiation of vegetative and sexual areas. Hydrobiologia 151/152:205206.

Krueger-Hadfield SA, Kübler JE, Dudgeon SR (2013) Reproductive effort of Mastocarpus papillatus (Rhodophyta) along the California coast. J Phycol 49:271-281.

Lefebvre C, Destombe C, Godin J (1987) Le fonctionnement du carposporophyte de Gracilaria verrucosa et ses repercussions sur la strategic de reproduction. Cryptogam Algol 8:113-126.

Mckey D, Elias M, Pujol B, Duputié A (2010) The evolutionary ecology of clonally propagated domesticated plants. New Phytol 186:318-332.

Meneses I (1996) Sources of morphological variation in populations of Gracilaria chilensis Bird, McLachlan \& Oliveira of Chile. Rev Chil 69:35-44.

Obeso JR (2002) The cost of reproduction in plants. New Phytol 155:321-348.

Obeso JR (2004) A hierarchical perspective in allocation to reproduction from whole plant to fruit and seed level. PPEES 6:217-225. 
Prieto I, Westermeier R, Muller D (1991) Variation of phenophases of Gracilaria chilensis Bird, Mclachlan and Oliveira (Rhodophyta, Gigartinales), in laboratory and field culture conditions. Presence of mixed phases. Rev Chil 64:343-352.

R Core Team (2016) R: A language and environment for statistical computing. Vienna, Austria: R Foundation for Statistical Computing. Retrieved from http://www.R-proje ct.org/. Richerd S, Destombe C, Cuguen J, Valero M (1993) Variation of reproductive success in a haploid-diploid red alga, Gracilaria verrucosa: effects of parental identities and crossing distance. Am J Bot 80:1379-1391.

Robinson N, Winberg P, Kirkendale L (2013) Genetic improvement of macroalgae: status to date and needs for the future. J Appl Phycol 25:703-716.

Santelices B (1990) Patterns of reproduction, dispersal and recruitment in seaweeds. Oceanogr Mar Biol Annu Rev 28:177-276.Santelices B, Varela D (1995) Regenerative capacity of Gracilaria fragments: effects of size, reproductive state and position along the axis. J Appl Phycol 7:501-506.

Segnou CA, Fatokun CA, Akoroda MO, Hahn SK (1992) Studies on the reproductive biology of white yam (Dioscorea rotundata Poir.). Euphytica 64:197-203.

Simmonds NW (1997) A review of potato propagation by means of seed, as distinct from clonal propagation by tubers. Potato Res 40:191-214.

Smith BD (2016) Neo-Darwinism, niche construction theory, and the initial domestication of plants and animals. Evol Ecol 30:307-324.

Stearns SC (1992) The evolution of life histories. Oxford, UK: Oxford University Press. 
Usandizaga S, Buschmann AH, Camus C, Kappes JL, Arnaud-Haond S, Mauger S, Valero M, Guillemin ML (2019) Better off alone? Compared performance of monoclonal and polyclonal stands of a cultivated red alga growth. Evol Appl https://onlinelibrary.wiley.com/doi/pdf/10.1111/eva.12908.

Valero M, Guillemin ML, Destombe C, Jacquemin B, Gachon C, Badis Y, Buschmann AH, Camus C, Faugeron S (2017) Perspectives on domestication research for sustainable seaweed aquaculture. PIP 4:33-46.

Vieira VMNCS, Engelen AH, Huanel OR, Guillemin ML (2018a) Haploid females in the isomorphic biphasic life-cycle of Gracilaria chilensis excel in survival. BMC Evol Biol $18: 174$.

Vieira VMNCS, Engelen AH, Huanel OR, Guillemin ML (2018b) Differentiation of haploid and diploid fertilities in Gracilaria chilensis affect ploidy ratio. BMC Evol Biol 18:183.

Zeder MA (2015) Core questions in domestication research. Proc Nat Acad Sci 112:31913198.

Zhang QS, Li W, Liu S, Pan JH (2009) Size-dependence of reproductive allocation of Sargassum thunbergii (Sargassaceae, Phaeophyta) in Bohai Bay, China. Aquat Bot 91:194198.

Zou D, Gao K, ZuoXi R (2006) Seasonal pattern of reproduction of Hizikia fusiformis (Sargassaceae, Phaeophyta) from Nanao Island, Shantou, China. J Appl Phycol 18:195-201. 
Table 1: Differences in dry weight, thallus volume, length of primary and secondary fronds, number of cystocarps observed per centimetre of primary and secondary fronds and size of cystocarps between females from the natural population of Dichato and the crop of Lenga. Bold characters represent significant values (*Mann-Whitney U Test; ${ }^{\$}$ Student $\mathrm{T}$ test) after a Bonferroni correction for multiple tests; 20 individual measured per locality; values are means \pm SE. n.a.: not applicable.

\begin{tabular}{|c|c|c|c|c|c|}
\hline Variables & $\begin{array}{c}\text { Natural } \\
\text { Population } \\
\text { Dichato }\end{array}$ & $\begin{array}{c}\text { Crop Population } \\
\text { Lenga }\end{array}$ & df & t-value & $p$-value \\
\hline Dry weight $(\mathrm{g})$ & $8.39 \pm 5.82$ & $50.09 \pm 39.54$ & 40 & -6.55 & $\left({ }^{\$}\right)<0.001$ \\
\hline Volume of the thallus $\left(\mathrm{cm}^{3}\right)$ & $82.84 \pm 70.96$ & $291.01 \pm 145.65$ & 30 & -5.84 & $\left({ }^{\$}\right)<0.001$ \\
\hline Length of primary fronds $(\mathrm{cm})$ & $8.93 \pm 4.88$ & $27.54 \pm 7.57$ & 30 & -9.89 & $\left({ }^{\$}\right)<0.001$ \\
\hline Number of cystocarps per centimetre of primary frond & $2.09 \pm 1.27$ & $0.26 \pm 0.28$ & n.a. & n.a. & $\left(^{*}\right)<0.001$ \\
\hline Length of secondary fronds $(\mathrm{cm})$ & $5.29 \pm 2.08$ & $7.94 \pm 2.66$ & 38 & -4.00 & $\left({ }^{\$}\right)=0.001$ \\
\hline Number of cystocarps per centimetre of secondary frond & $2.00 \pm 0.93$ & $0.17 \pm 0.22$ & n.a. & n.a. & $\left(^{*}\right)<0.001$ \\
\hline Average size of cystocarps (mm) & $1.05 \pm 0.34$ & $1.66 \pm 0.57$ & 22 & -1.45 & $(\$)=0.140$ \\
\hline
\end{tabular}




\section{Figure legends}

Fig. 1. Map of the Chilean coast (A) and of the Concepción region, where Dichato and Lenga are located (B). Photographs of the natural population of Dichato (C) and of the crop of Lenga, note the Agarophyton chilense collected by Lenga residents forming piles on the beach (D). All photographs by C. Destombe.

Figure 2: Relation between the primary frond length $(\mathrm{cm})$ and the number of cystocarps observed per centimetre of primary frond (no. of cystocarps $\cdot \mathrm{cm}^{-1}$ ) in Agarophyton chilense from Dichato (A) and Lenga (B). Each data point represents individual average value; solid line represents the least square linear regression (rs: Spearman rank correlation coefficient, $p$ : probability level).

Figure 3. Photograph of female thalli from Dichato - details of cystocarps growing on the thallus are given in insert - (A) and Lenga (B). Cross-section of cystocarps (arrowheads: carpospores) from Dichato (C) and Lenga (D). Black line represents $5 \mathrm{~cm}$ in (A) and (B) and $80 \mu \mathrm{m}$ in (C) and (D). All photographs by M-L. Guillemin. Ca: carposporangium (corresponding to a carpospore not yet released), cc: female cortical cell, cy: cystocarp, fm: female medulla, ft: female thallus, g: gonimoblast, p: pericarp. 


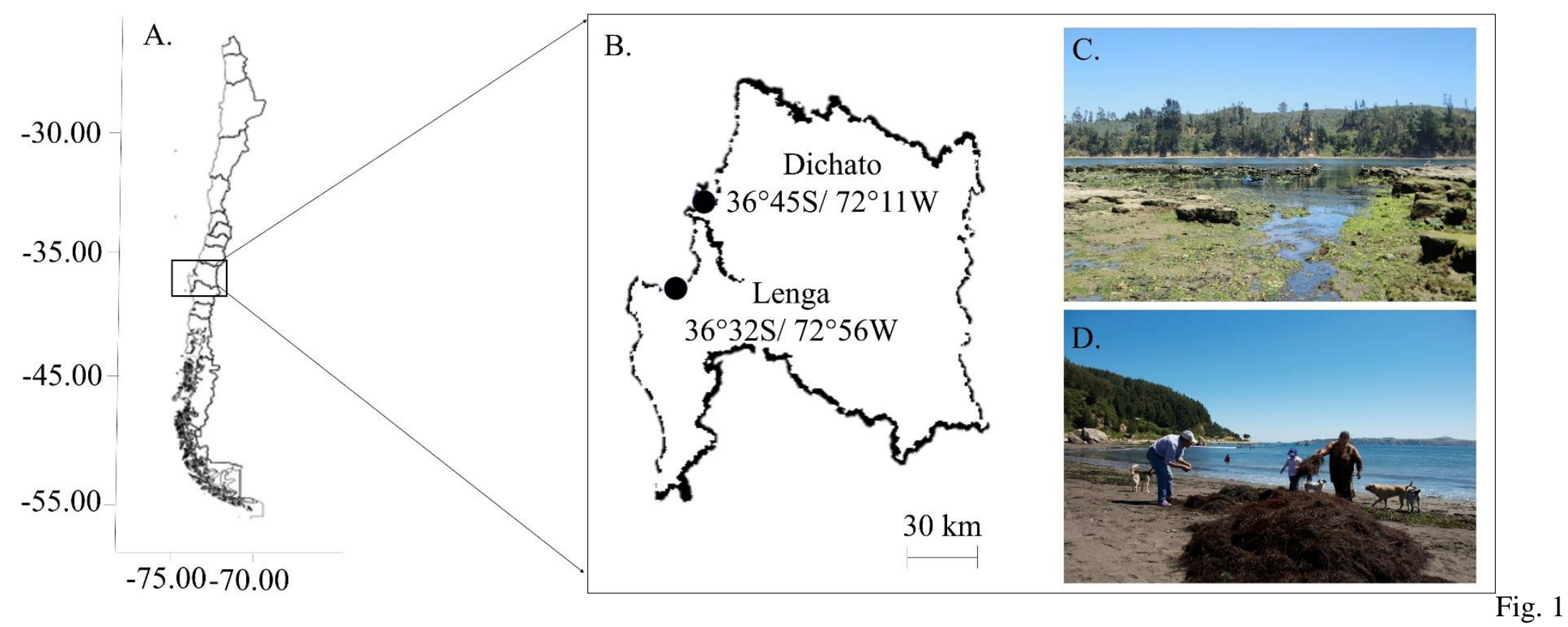



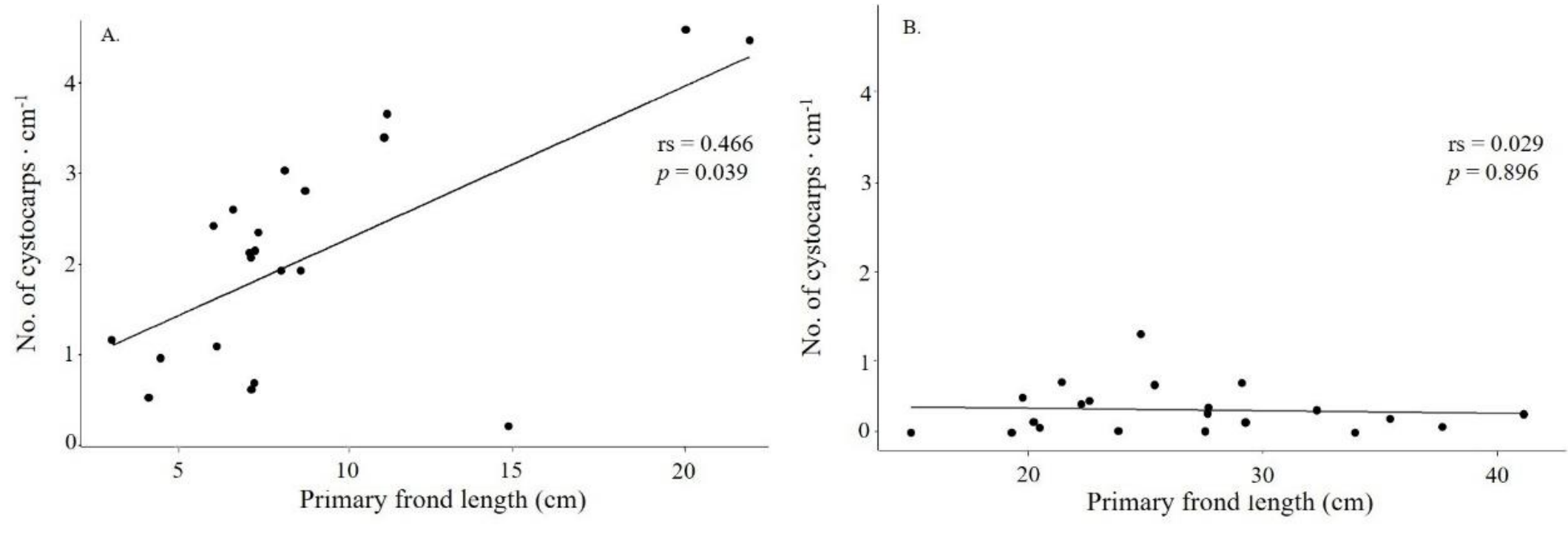

Fig. 2 


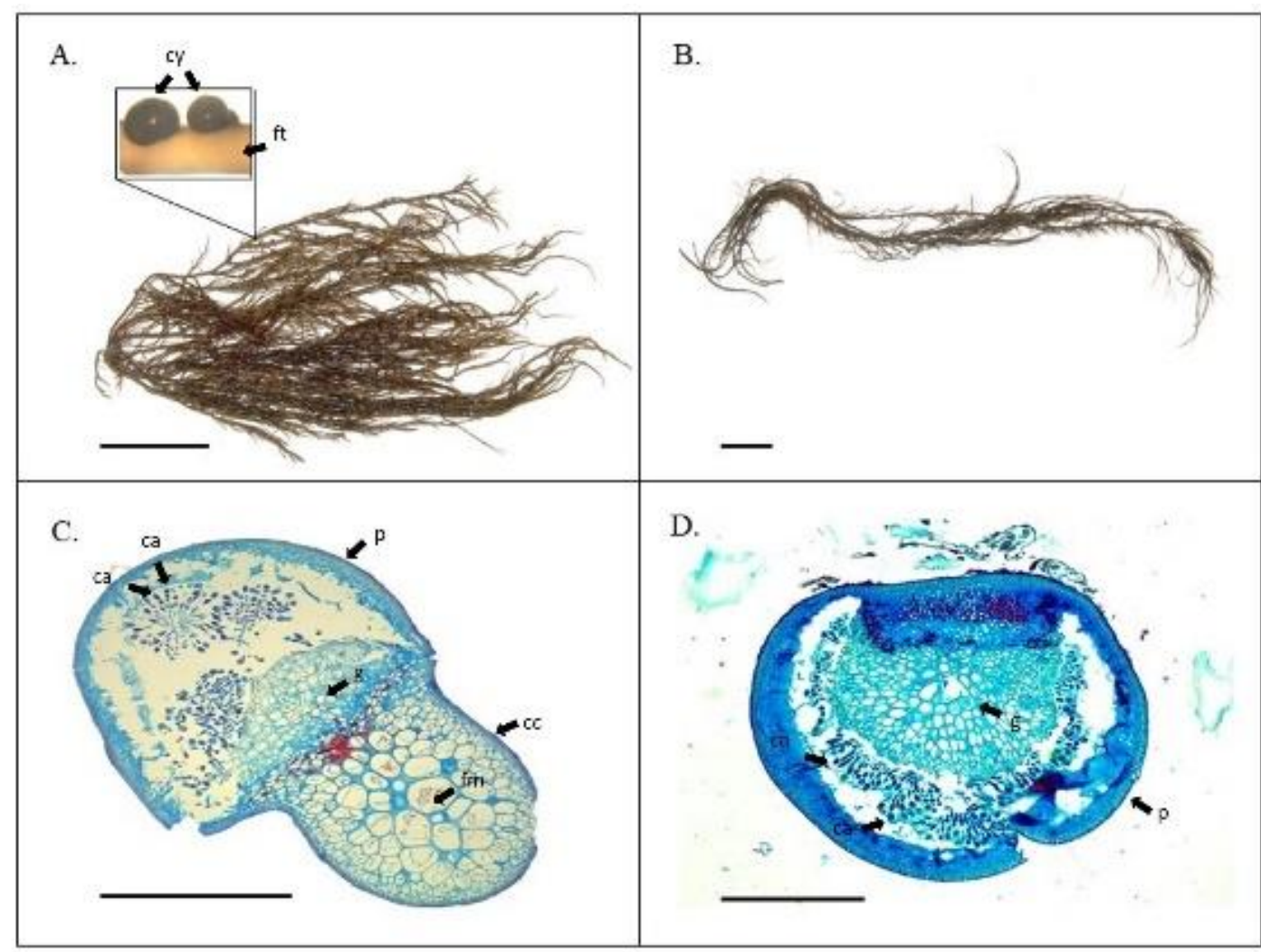

Fig. 3 